Endocrinol. Japon. 1989, 36 (6), 787-793

\title{
Effect of GRF and Somatostatin on 7B2 Secretion by Rat $\mathbf{G H}_{1}$ Cells
}

\author{
Haruo IGUCHI $^{1}$, Shoichi NATORI ${ }^{2}$ and Hajime NAWATA ${ }^{2}$ \\ ${ }^{1}$ Department of Biochemistry, National Kyushu Cancer Center, \\ Fukuoka 815, Japan
}

${ }^{2}$ Third Department of Internal Medicine, Faculty of Medicine, Kyushu University, Fukuoka 812, Japan

\begin{abstract}
A novel pituitary protein "7B2" was secreted by $\mathrm{GH}_{1}$ cells. The secretion of 7B2 was increased in the presence of human GRF in a dose-responsive manner. In contrast, a somatostatin analog, SMS 201-995, revealed the inhibitory effects on the basal- and GRF-induced secretion of 7B2 at the concentration of $10^{-7} \mathrm{M}$. These findings suggest that $7 \mathrm{~B} 2$ is a secretory protein of rat $\mathrm{GH}_{1}$ cells under certain conditions.
\end{abstract}

A novel protein "7B2", initially isolated from human and porcine pituitary glands (Hsi et al., 1982; Seidah et al., 1983), is distributed widely in the rat, with high concentrations in the neuroendocrine tissues (Iguchi et al., 1984). Immunocytochemical studies revealed the presence of 7B2 in the gonadotrophs and thyrotrophs of the rat pituitary gland (Marcinkiewicz et al., 1987). Release of 7B2 induced by high $\mathrm{K}^{+}$and/or LHRH was also demonstrated using cultured cells of the rat pituitary gland (Iguchi et al., 1984; Deng et al., 1986). These observations indicate that $7 \mathrm{~B} 2$ is a secretory protein in the rat pituitary gland. The presence of $7 \mathrm{~B} 2$ was also noted in the

Received March 28, 1989

All correspondence to: HARUO IGUCHI, M.D., Department of Biochemistry, National Kyushu Cancer Center, 3-1-1 Notame, Minami-ku, Fukuoka 815, Japan. human GH-producing pituitary adenoma and an increase in plasma 7B2 after an administration of GRF was found in some patients with acromegaly but not in normal subjects (Natori et al., 1988). These findings suggest that $7 \mathrm{~B} 2$ could be secreted by human GH-producing pituitary adenoma and its secretion is regulated by GRF.

This work was undertaken in order to investigate $7 \mathrm{~B} 2$ secretion under certain conditions by the rat adenomatous $\mathrm{GH}$ secreting cells $\left(\mathrm{GH}_{1}\right.$ cells $)$.

\section{Materials and Methods}

\section{Cell culture}

$\mathrm{GH}_{1}$ cells, established from rat $\mathrm{GH}$ secreting pituitary tumor, were obtained from American Type Culture Collection (Rockville, Maryland, USA) and maintained in T-flasks (Corning Glass Works, Corning, NY, USA) as a monolayer cul- 
ture in Ham's F-10 medium supplemented with horse serum (15\%) and fetal bovine serum (FBS) $(2.5 \%)$. Culture reagents were purchased from Gibco (Grand Island, NY, USA). Human GRF (1-44) $\mathrm{NH}_{2}$ (hGRF) was purchased from Peptide Institute (Minoh, Japan) and SMS 201-995 was a gift from Sandoz Ltd. (Basel, Switzerland). The cells were detached from the surface of the T-flasks by the trypsin treatment and replated in the $35 \mathrm{~mm}$-dishes (Corning) at a density of $5 \times$ $10^{5}$ cells/dish. On the 3 rd day after replating, the release experiment was performed. The medium was removed and the cells were washed twice with $2 \mathrm{ml}$ Ham's F-10 containing $2.5 \%$ FBS. Then, $1 \mathrm{ml}$ Ham's F-10 containing $2.5 \%$ FBS with $\mathrm{KCl}(50 \mathrm{mM}), \operatorname{hGRF}\left(10^{-7}, 10^{-6}, 10^{-5} \mathrm{M}\right)$, SMS 201-995 $\left(10^{-9}, 10^{-7}, 10^{-5} \mathrm{M}\right)$ and hGRF $\left(10^{-6}\right.$ M) + SMS 201-995 $\left(10^{-9}, 10^{-7}, 10^{-5} \mathrm{M}\right)$ were added and the cells were allowed to incubate for $1 \mathrm{~h}$ at $37^{\circ} \mathrm{C}$ under $5 \% \mathrm{CO}_{2}-95 \%$ air. The medium was collected at the termination of incubation and centrifuged at $200 \times \mathrm{g}$ for $5 \mathrm{~min}$ to remove desquamated cells, and the supernatant was stored at $-20^{\circ} \mathrm{C}$ until assay. The cells in each dish were scraped into $1 \mathrm{ml}$ of $1 \mathrm{M}$ acetic acid and extracted by sonication. After centrifugation, the supernatant was stored at $-20^{\circ} \mathrm{C}$ until assay.

Protein concentrations of the cell extracts were determined with a Bio-Rad protein assay kit (Richmond, CA, USA) with BSA as a standard.

\section{Gel permeation chromatography}

Gel permeation chromatography of the culture medium and cell extract was performed on a Sephadex G-100 column $(95 \times 1.4 \mathrm{~cm})$. Samples $(2 \mathrm{ml})$ were layered onto the column and eluted with $1 \mathrm{M}$ acetic acid at $7 \mathrm{~m} 1 / \mathrm{h}$ at $4^{\circ} \mathrm{C}$. Each fraction $(1.3 \mathrm{ml})$ was dried with a centrifugal concentrator (Taiyo VC-36, Taiyo Scientific Industrial Co. LTD., Tokyo Japan) and reconstituted with RIA-buffer before assay. The column was calibrated with protein markers (Vo, catalase ; 43K, ovalbumin ; 25K, chymotrypsinogen $\mathrm{A} ; 13.7 \mathrm{~K}$, ribonuclease).

\section{RIA}

Immunoreactive (IR)-7B2 was measured by RIA as described previously (Iguchi et al., 1984). A 7B2 antiserum was raised against a synthetic fragment of 7B2, corresponding to amino acids $23-39$ of authentic porcine 7B2 (7B2 23-39), coupled to bovine thyroglobulin in rabbits. The antiserum did not cross-react with POMC-related peptides, GH, LH, FSH, TSH, PRL, AVP, oxytocin, neurophysin, CRF, GRF, somatostatin, calcitonin, insulin, glucagon, pancreatic polypeptide, secretin, substance $P$, dynorphin 1-13, Met ${ }^{5}$-enkephalin and thyroglobulin. 7B2 23-39 and ${ }^{125}$ I-7B2 23-39 were used as standard and tracer, respectively. Intraand interassay coefficients of variation were $9 \%$ and $12 \%$, respectively $(n=5)$. Dilution curves of the culture medium and cell extract revealed a paralle1 displacement with a RIA standard curve (data not shown).

GH was measured by double-antibody RIA using materials provided by the NIADDK Rat Pituitary Hormone Distribution Program. Intraand interassay coefficients of variation were less than $15 \%(n=3)$.

\section{Statistics}

Student's $t$-test was performed to assess the significant difference between medium concentrations of IR-7B2 or GH in each group.

\section{Results}

\section{Contents of IR-7B2 and $G H$ in $G H_{1}$ cells}

Cell contents of IR-7B2 and GH (mean $\pm \mathrm{SD}, \mathrm{n}=8$ ) were $943 \pm 276$ and $2127 \pm 177$ $\mathrm{fmol} / \mathrm{mg}$ protein, respectively.

\section{Effects of high $K^{+}$and hGRF on the secretion of IR-7B2 and $G H$ by $G_{1}$ cells}

IR-7B2 was secreted by $\mathrm{GH}_{1}$ cells and the secretion of IR-7B2 was increased about 3-fold by high $\mathrm{K}^{+}$-induced depolarization (data not shown). GH was also secreted by high $\mathrm{K}^{+}$but the magnitude of the increase was less than that of IR-7B2 (data not shown). The medium concentration of IR-7B2 was significantly increased in the presence of $10^{-6} \mathrm{M}(\mathrm{P}<0.01)$ and $10^{-5} \mathrm{M}$ hGRF $(P<0.01)$, but secretion of IR-7B2 remained unchanged in the presence of $10^{-7} \mathrm{M}$ hGRF (Fig. 1). The medium concentration of $\mathrm{GH}$ was also increased in the presence of $10^{-5} \mathrm{M}$ hGRF $(\mathrm{p}<0.05)$ (Fig. 1). 
In the presence of $10^{-7}$ and $10^{-6} \mathrm{M}$ hGRF the medium $\mathrm{GH}$ concentrations tended to increase, but the increase was not statistically significant (Fig. 1).
Effects of SMS201-995 on the basal and GRF $\left(10^{-6} M\right)$-induced secretion of IR-7B2 and $G H$ by $G_{1}$ cells

As shown in Fig. 2, the addition of SMS 201-995 caused a significant decrease

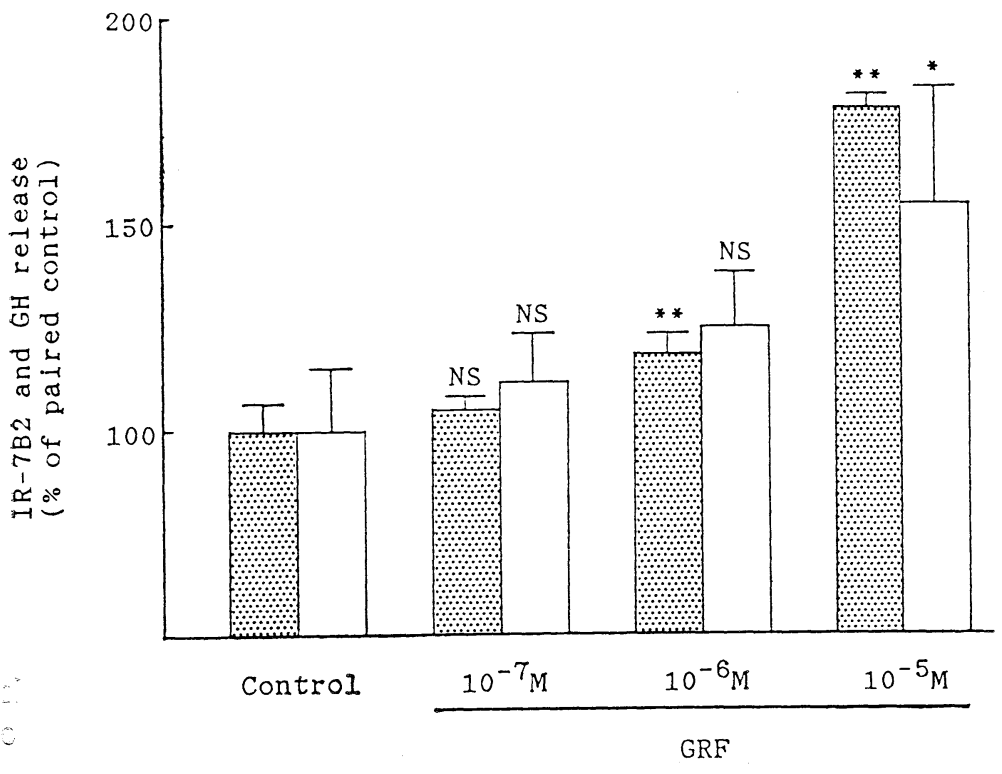

Fig. 1. Effects of GRF $\left(10^{-7}, 10^{-6}\right.$ and $\left.10^{-5} \mathrm{M}\right)$ on the secretion of IR$7 \mathrm{~B} 2$ and $\mathrm{GH}$ by $\mathrm{GH}_{1}$ cells. Each bar represents the mean $( \pm S D)$ concentrations of IR7B2 (m) and $\mathrm{GH}$ $(\square)$ in the medium after the 1h-incubation with or without GRF in the four replicate dishes. $* \mathrm{P}<0.05, * *$ $\mathrm{P}<0.01$ (vs. paired control)

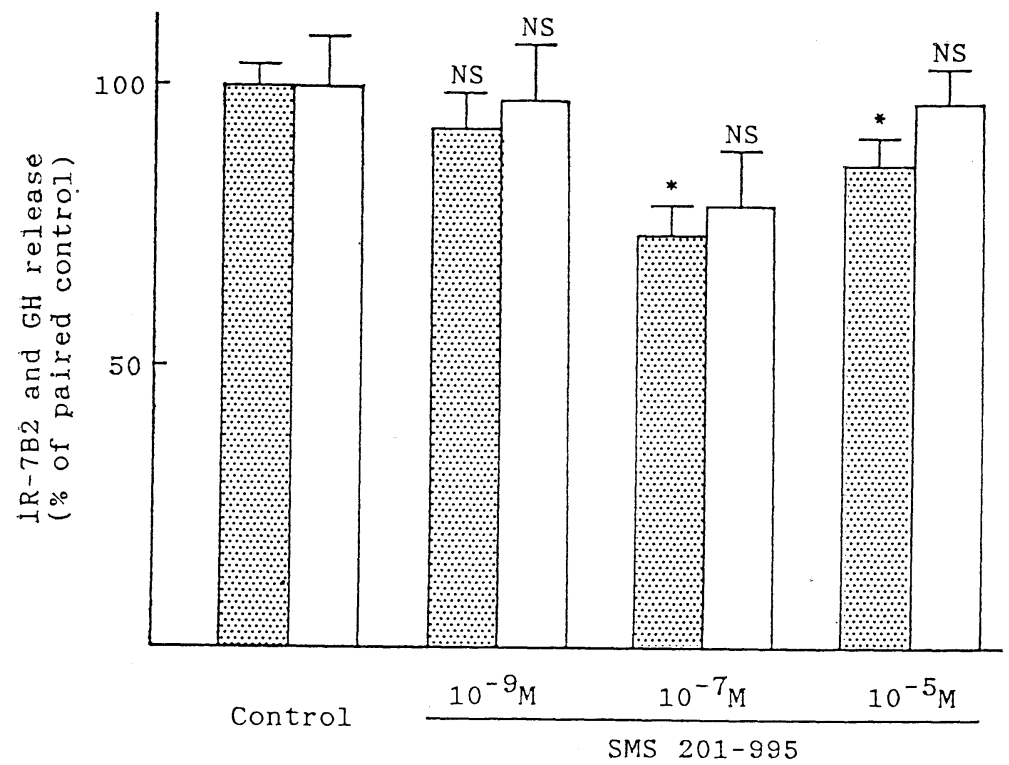

Fig. 2. Eî̃ects of SMS 201-995 $\left(10^{-9}, 10^{-7}\right.$ and $10^{-5} \mathrm{M}$ ) on the basal secretion of IR-7B2 and $\mathrm{GH}$ by $\mathrm{GH}_{1}$ cells. Each bar represents the mean $( \pm \mathrm{SD})$ concentrations of IR-7B2 ( and GH $(\square)$ in the medium after the $1 \mathrm{~h}$ incubation in the presence or absence of SMS 201-995 in the four replicate dishes. $* \mathrm{P}<0.01$ (vs. paired control) 


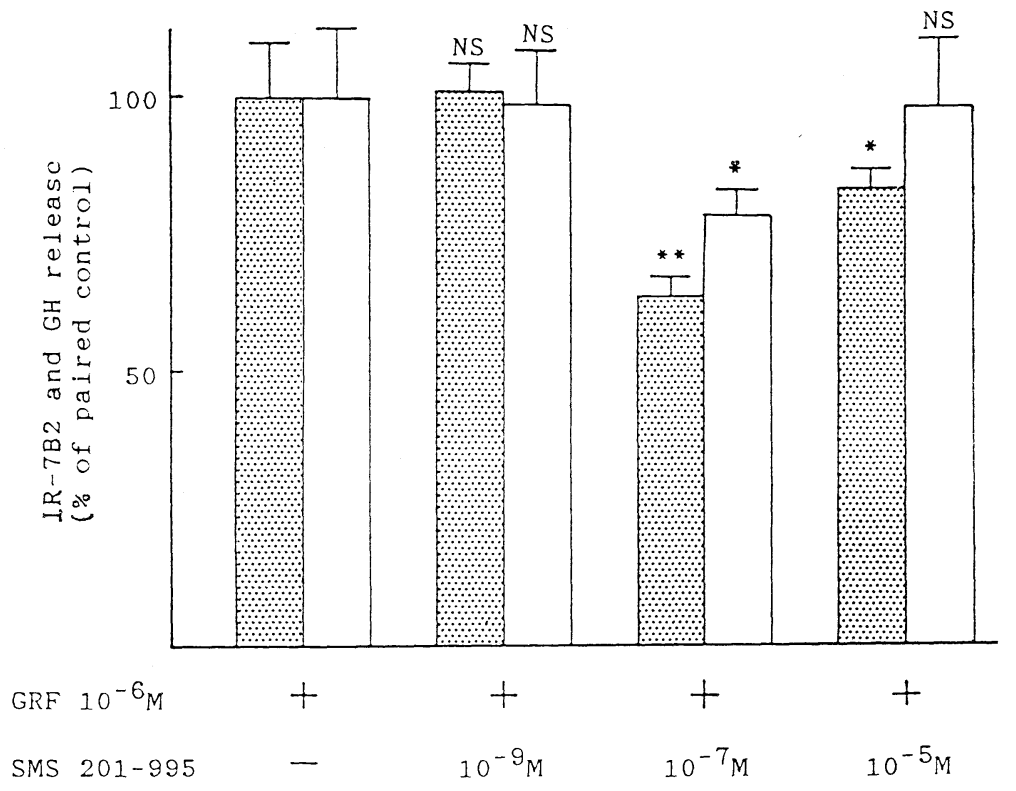

Fig. 3. Effects of SMS 201-995 $\left(10^{-9}, 10^{-7}\right.$ and $10^{-5} \mathrm{M}$ ) on the GRF $\left(10^{-6} \mathrm{M}\right)$-induced secretion of IR-7B2 and $\mathrm{GH}$ by $\mathrm{GH}_{1}$ cells. Each bar represents the mean $( \pm \mathrm{SD})$ concentra-

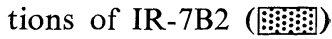
and $\mathrm{GH}(\square)$ in the medium after the lh-incubation with or without SMS 201-995 in the presence of $10^{-6}$ M GRF. Four dishes were used for each group. $* \mathrm{P}<0.05, \quad * * \mathrm{P}<0.01$ (vs. paired control) in the basal secretion of IR-7B2 at the concentration of $10^{-7} \mathrm{M}(\mathrm{P}<0.01)$, however, the maximal inhibition was obtained at $10^{-7} \mathrm{M}$ and the higher dose was toxic to the cells. Such inhibition by SMS 201-995 of GH secretion was also noted, but it was not statistically significant (Fig. 2). Similar1y, hGRF $\left(10^{-6} \mathrm{M}\right)$-induced secretion of IR$7 \mathrm{~B} 2$ was significantly decreased in the presence of SMS201-995 at the concentration of $10^{-7} \mathrm{M}(\mathrm{P}<0.01)$ and $10^{-5} \mathrm{M}(\mathrm{P}<0.05)$, and this inhibitory effect of SMS 201-995 was maximum at $10^{-7} \mathrm{M}$ (Fig. 3). GH secretion in the presence of $10^{-6} \mathrm{M}$ hGRF was significantly inhibited by $10^{-7} \mathrm{M}$ SMS 201-995 ( $\mathrm{P}<0.05)$ although $10^{-6} \mathrm{M}$ hGRF did not cause a significant increase in the medium GH concentration (Fig. 3).

\section{Gel permeation chromatography}

Fig. 4 depicts the elution profiles of the cell extract and culture medium of $\mathrm{GH}_{1}$ cells on a Sephadex G-100 column. One peak of IR-7B2 with an apparent mol wt of $45 \mathrm{~K}$ was found in the cell extract, whereas a major peak of IR-7B2 with an apparent mol wt of $45 \mathrm{~K}$ and a minor peak with an apparent mol wt of $13 \mathrm{~K}$ were found in the culture medium (Fig. 4).

\section{Discussion}

$7 \mathrm{~B} 2$ is a scretory protein of the neuroendocrine tissues of several species (Iguchi et al., 1984; Deng et al., 1986; Iguchi et al., 1987 ; Natori et al., 1988 ; Venetikou et al., 1988). 7B2 is present in human plasma and an increase in plasma 7B2 was noted in some patients with various endocrine tumors (Suzuki et al., 1986; Iguchi et al., 1987). Increased plasma 7B2 in these patients could be attributed to the secretion of $7 \mathrm{~B} 2$ by the tumors, although the origin of plasma 7B2 in normal humans is uncertain. Recently, Natori et al. (1988) observed an increase in plasma 7B2 in response to $\mathrm{GRF}$ in vivo and a high $\mathrm{K}^{+}$induced release of 7B2 in vitro in acromegalic patients. However, little is known of the 


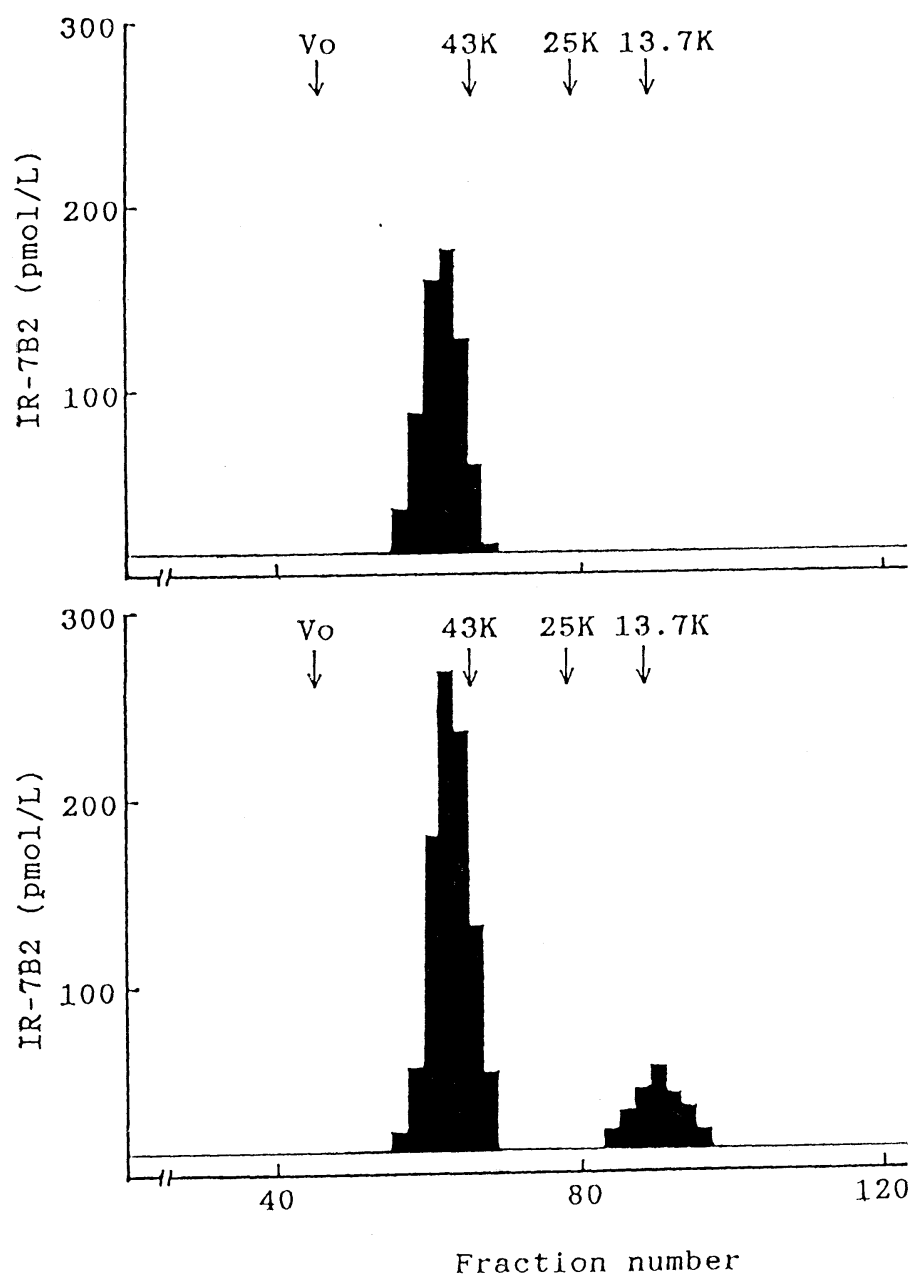

Fig. 4. Gel permeation chromatography of the cell extract (upper panel) and culture medium (lower panel) of $\mathrm{GH}_{1}$ cells on a Sephadex G-100 column $(95 \times$ $1.4 \mathrm{~cm})$. Samples $(2 \mathrm{ml})$ were layered onto the column and eluted at $7 \mathrm{ml} / \mathrm{h}$ at $4 \mathrm{C}$. Each fraction was assayed for 7B2. Molecular markers are Vo, catalase; $43 \mathrm{~K}$, ovalbumin; $25 \mathrm{~K}$, chymotrypsinogen $\mathrm{A}$ and $13.7 \mathrm{~K}$, ribonuclease.

mechanism regulating $7 \mathrm{~B} 2$ secretion from these tissues. Clonal lines of rat pituitary tumor cells (GH cells) are widely used in studies of the mechanism regulating of pituitary function. Inhibition of membrane adenylate cyclase activity by somatostatin was demonstrated in $\mathrm{GH}_{1}$ cells (Heindel et al., 1978), but GH release from the cells induced by GRF has not been reported to my knowledge. In $\mathrm{GH}_{3}$ cells, on the other hand, hGRF did not affect either the secretion of $\mathrm{GH}$ by the cells or the cellular GH-mRNA concentration (Zeytin et al.,
1984). Thus, we used $\mathrm{GH}_{1}$ cells and studied the responsiveness of these cells to hGRF or somatostatin. IR-7B2 was secreted by $\mathrm{GH}_{1}$ cells and this secretion of IR-7B2 was increased by adding hGRF in a doseresponsive manner. On the other hand, the somatostatin analog SMS201-995 inhibited the basal secretion of IR-7B2 as well as the hGRF-induced IR-7B2 secretion. These findings suggest that $7 \mathrm{~B} 2$ is a secretory protein of the rat $\mathrm{GH}_{1}$ cells and that this secretion of $7 \mathrm{~B} 2$ is under certain control. In human subjects, on the other hand, an 
increase in plasma 7B2 after an i. v. bolus infusion of GRF was noted only in patients with acromegaly (Natori et al., 1988). This suggests the GRF-induced.secretion of 7B2 by the $\mathrm{GH}$ secreting pituitary adenoma. 7B2 has been shown to be present in gonadotrophs and thyrotrophs of the rat pituitary gland (Marcikiewicz et al., 1987). However, present studies together with the fiindings described by Natori et al. (1988) suggest the presence of $7 \mathrm{~B} 2$ in the adenomatous $\mathrm{GH}$ secreting cells in the human and rat. 7B2 may be applicable to a clinical utility as a marker for acromegaly.

A significant increase in the medium GH concentration after an addion of $10^{-5} \mathrm{M}$ hGRF was also noted, although its effect on hGRF was weak. This suggests that $\mathrm{GH}$ release is induced hy hGRF even in $\mathrm{GH}_{1}$ cells. Such a weak effect of hGRF on the $\mathrm{GH}$ secretion by the cells may be due to species' difference of GRF. The magnitude of the increase or decrease in IR-7B2 and $\mathrm{GH}$ in the presence of hGRF or a somatostatin analog were different. This may be attributed to the localization of IR-7B2 and GH in the different secretory granules.

In the analysis of the molecular form of IR-7B2 on gel permeation chromatography, different elution profiles were obtained, i. e. only a $45 \mathrm{~K}$-peak in the cell extract and $45 \mathrm{~K}$ - and $13 \mathrm{~K}$-peaks in the culture medium. Earlier studies revealed that the $45 \mathrm{k}$-peak of IR-7B2 obtained by gel permeation chromatography shifted to $20-22 \mathrm{~K}$ in the analysis on SDS-PAGE under the reduced condition (Iguchi et al., 1984). The mol wt of 7B2, deduced from the human pituitary cDNA, is 20793 (Martens, 1988). Thus, the 45K-7B2 could be a dimer. On the other hand, the smaller mol wt form of IR-7B2 (13K) was found only in the culure medium. A 7B2 molecule contains three sites for possible proteolytic cleavage (Martens, 1988) and the $\mathrm{N}$-terminal amino acid sequence of $13 \mathrm{~K}-7 \mathrm{~B} 2$ was identical with that of $22 \mathrm{~K}-7 \mathrm{~B} 2$ in the human tissues (Marcinkiewicz et al., 1986). The 13K-7B2 found in the culture medium in the present study is likely to be a flanking peptide after proteolytic cleavage. A possible explanation for the presence of $13 \mathrm{~K}-7 \mathrm{~B} 2$ only in the culture medium is that a 7B2 molecule is processed into small fragments including $13 \mathrm{~K}-7 \mathrm{~B} 2$ in the secretory granules just before secretion. We cannot exclude the possibility that the $13 \mathrm{~K}-7 \mathrm{~B} 2$ is a degradation product produced during storage.

\section{Acknowledgement}

We thank Dr. Michel Chretien (Clinical Research Institute of Montreal, Montrea1, Canada) for providing the $7 \mathrm{~B} 2$ antiserum and a synthetic fragment of 7B2 (7B223-39), Dr. K. Chihara (Kobe University, Kobe, Japan) for comments on the manuscript and Miss K. Kichise for secretarial services. This work was supported in part by a Grant-in-Aid for Cancer Research (61-1) from the Ministry of Health and Welfare of Japan.

\section{References}

Deng, J. Y., J. S. D. Chan, N. G. Seidah and M. Chretien (1986). Specific release of a novel pituitary polypeptide, 7B2, from rat anterior pituitary cells in vitro by luteinizing hormone releasing hormone. Neuroendocrinology 44, 373-377.

Heinde1, J. J., E. Williams, G. A. Robinson and S. J. Strada (1978). Inhibition of $\mathrm{GH}_{1}$ rat pituitary tumor cell adenylyl cyclase activity by somatostatin. J. Cyclic Nucleotide Res. 4, 453-457.

Hsi, K. L., N. G. Seidah, G. DeSerres and M. Chretien (1982). Isolation and $\mathrm{NH}_{2}$-terminal sequence of a novel porcine anterior pituitary polypeptide. FEBS Lett. 147, 261-266.

Iguchi, H., J. S. D. Chan, N. G. Seidah and M. Chretien (1984). Tissue distribution and molecular forms of a novel pituitary protein in the rat. Neuroendocrinology 34, 453-458.

Iguchi, H., J. S. D. Chan, N. G. Seidah and 
M. Chretein (1987). Evidence for a nove1 pituitary protein (7B2) in human brain, cerebrospinal fluid and plasma: Brain concentrations in controls and patients with Alzhimer's disease. Peptides 8, 593-598.

Iguchi, H., S. Natori, H. Nawata, K. Kato, H. Ibayashi, J. S. D. Chan, N. G. Seidah and M. Chretien (1987). Presence of the novel pituitary protein "7B2" in bovine chromaffin granules: Possible co-release of $7 \mathrm{~B} 2$ and catecholamine as induced by nicotine. $J$. Neurochem. 49, 1810-1814.

Marcinkiewicz, M., S. Benjannet, M. Cantin, N. G. Seidah and M. Chretien (1986). CNS distribution of a novel pituitary protein '7B2': Localization in secretory and synaptic vesicles. Brain Res. 380, 349-356.

Marcinkiewicz, M., S. Benjannet, N. G. Seidah, M. Cantin and M. Chretien (1987). The pituitary polypeptide "7B2" is associated with LH/FSH and TSH cells and is localized within secretory vesicles. Cell Tissue Res. 250, 205214.

Natori, S., H. Iguchi, H. Nawata, K. Kato, H. Ibayashi, H. Nakagaki and $M$. Chretien (1988). Evidence for the release of a novel pituitary polypeptide (7B2) from the growth hormone-producing pituitary adenoma of patients with acromegaly. J. Clin. Endocrinol.
Metab. 66, 430-437.

Seidah, N. G., K. L. Hsi, G. DeSerres, Y. Rochemont, J, Hamelin, T. Antakly, M. Cantin and M. Chretien (1983). Isolation and $\mathrm{NH}_{2}$-terminal sequence of a highly conserved human and porcine pituitary protein belonging to a new superfamily: Immunocytochemical localization in pars distalis and pars nervosa of the pituitary and in the supraoptic nucleus of the hypothalamus. Arch. Biochem. Biophys. 225, 525-534.

Suzuki, H., M. A. Ghatei, S. J. Williams, L. O. Uttentha1, P. Facer, A. E. Bishop, J. M. Polak and S. R. Bloom (1986). Production of pituitary protein $7 \mathrm{~B} 2$ immunoreactivity by endocrine tumors and its possible diagnostic value. J. Clin. Endocrinol Metab. 63, 758765.

Venetikou, M.S., M. A. Ghatei, J. M. Burrin, S. Latif and S. R. Bloom (1988). 7B2, a new protein secreted by human functionless pituitary tumours, in vitro. Acta Endocrinol. 118, 521527.

Zeytin, F. N., G. G. Gick, P, Brazeau, N. Ling, M. McLaughlin and C. Bancroft (1984). Growth hormone (GH)-releasing factor does not regulate GH release or GH mRNA levels in $\mathrm{GH}_{3}$ cells. Endocrinology 114, 2054-2059. 